\title{
ALLELOPATHIC EFFECTS OF SUNFLOWER RESIDUE ON GROWTH OF RICE AND SUBSEQUENT WHEAT CROP
}

\author{
Uzma Bashir $^{1 *}$, Arshad Javaid ${ }^{1}$, and Rukhsana Bajwa ${ }^{1}$
}

Sunflower (Helianthus annuus L.) is a well known allelopathic plant species. However, Pakistani farmers generally incorporate the sunflower residue in the soil with the aim to enhance soil fertility and organic matter. Field experiments were, therefore, carried out to evaluate the effect of sunflower residue incorporation on growth and yield of rice (Oryza sativa L.) and subsequent wheat (Triticum aestivum L.) crop. For rice crop, there were four treatments viz. control, sunflower residue incorporation (RI), NPK fertilizers, and NPK+RI. Two rice varieties (Basmati Pak and Basmati Super) were cultivated. Incorporation of sunflower residue markedly reduced plant growth and yield in 'Basmati Pak'. There was 34\% reduction in yield of this variety due to RI. 'Basmati Super' was tolerant to sunflower allelopathy, where the effect of RI was generally insignificant on plant growth and grain yield. Two commonly cultivated varieties of wheat (Inqalab 91 and Punjab 96) were sown in the same plots after harvesting the rice, without any addition of either RI or NPK. In 'Punjab 96', the effect of RI or RI+NPK was insignificant on grain yield. In contrast, in 'Inqalab 91', RI in combination with NPK fertilizers significantly reduced the grain yield by $41 \%$ as compared to NPK alone. The present study concluded that rice 'Basmati Super' and wheat 'Punjab 96' are suitable for cultivation under sunflower allelopathic stress.

Key words: Allelopathy, genotypic tolerance, Oryza sativa, Helianthus annuus, Triticum aestivum.

$\mathrm{T}$ he potential impacts of allelopathy on agriculture have been described during last 40 years. Many crops have been reported to be allelopathic towards other crops grown either simultaneously or subsequently (Chattopadhyay, 1995; Kawata et al., 1996; Khanh et al., 2005). Consequently, it has been suggested that crops with allelopathic effect on the other crops should not be followed by susceptible ones (Kausar, 1999). Roth et al. (2000) observed that Sorghum bicolor (L.) Moench frequently reduced grain yield of wheat (Triticum aestivum L.) when the crops are grown in rotation. Oleszek and Jurzysta (1987) reported wheat seed germination and seedling growth were suppressed by water and alcohol extracts of alfalfa (Medicago sativa L.) roots. This phenomenon has also been reported in other crops like corn (Zea mays L.) and oat (Avena sativa L.) (Nielsen et al., 1960; Al-Tawaha and Odat, 2010), rice (Oryza sativa L.) (Hisashi, 2004; Javaid et al., 2008) and cotton (Gossypium hirsutum L.) (Ioannis et al., 2005). The allelopathic effects are selective, depending upon the concentrations and residue type, either inhibitory or stimulatory to the growth of companion or subsequent crops or weeds (Mushtaq et al., 2003; Cheema et al., 2004; Javaid et al., 2007).

${ }^{1}$ University of the Punjab, Institute of Agricultural Sciences, Quaide-Azam Campus Lahore 54590, Pakistan.

"Corresponding author (uzmamppl@yahoo.com).

Received: 4 October 2011

Accepted: 13 June 2012.
Sunflower (Helianthus annuus L.) is recognized as an important crop in several areas of Pakistan due to suitability of the crop to local agroclimatic conditions, its importance as source of edible oil and protein, resistance to drought and its short duration (Kamal and Bano, 2009). However, yields of some crops following sunflower are lower than normal, possibly because of inadequate nutrition and chemical inhibition (Kamal and Bano, 2008). More than 200 natural allelopathic compounds have been isolated from different cultivars of sunflower (Kamal and Bano, 2009). Sunflower leaf extracts caused reduction in radical and hypocotyl length of mustard seedling (Wardle et al., 1991; Bogatek et al., 2006). Sedigheh et al. (2010) observed that sunflower parts significantly inhibit the germination of Solanum nigrum L. Being a short duration and economically important crop, sunflower is cultivated twice a year (spring and autumn) in Pakistan. However, generally sunflower is cultivated on larger scale in spring than in autumn season. Spring sown sunflower is cultivated during March-April and is harvested in June in Pakistan. Generally, it is followed by rice cultivation. In past farmers used to burn sunflower residue after harvest. Nowadays, sunflower residue is generally incorporated in the soil with the idea that it will add to the organic matter and fertility of the soil. The allelochemicals released from crop residues in the soil are likely to cause adverse effects on the proceeding crops, and such detrimental interactions cannot be over looked in rice-wheat cropping system in the country. The present study was, therefore, designed 
to investigate the effect of incorporation of sunflower residue on growth and yield of two rice varieties and two wheat varieties grown thereafter.

\section{MATERIALS AND METHODS}

\section{Incorporation of sunflower residue}

Certified seeds of sunflower var. Hysun 33 (Monsanto Pakistan (Pvt) Ltd.), commonly cultivated in Pakistan, were sown on ridges in $2 \times 2 \mathrm{~m}$ plots at a depth of $1 \mathrm{~cm}$ in March 2007. Seeds were planted with inter-row and interplant spacing of 75 and $30 \mathrm{~cm}$, respectively. A basal dose of $120 \mathrm{~kg} \mathrm{~N} \mathrm{ha}^{-1}$ as urea, $90 \mathrm{~kg} \mathrm{P}_{2} \mathrm{O}_{5} \mathrm{ha}^{-1}$ as triple super phosphate and $60 \mathrm{~kg} \mathrm{~K}_{2} \mathrm{O}$ ha $^{-1}$ as potassium sulfate was applied in each plot. Plots were irrigated as recommended for sunflower. After $90 \mathrm{~d}$ of sowing, mature sunflower plants were decapitated. Remaining vegetative parts were uprooted, cut into small pieces of 3-5 cm, mixed into the field soil up to the depth of $15-18 \mathrm{~cm}$ and left till the cultivation of rice crop in July.

\section{Cultivation of rice}

Two commonly grown rice varieties ('Basmati Pak' and 'Basmati Super') were selected for field study. Rice nursery was raised during June in field plots of $4 \times 6 \mathrm{~m}$. Plots were supplied with recommended fertilizer doses and regular irrigation and hand weeding was carried out as and when required. Forty days old seedlings of the two selected rice varieties were transferred to field plots with inter and intra row spacing of $22 \mathrm{~cm}$. There were four treatments: Control, sunflower residue incorporation (RI), NPK fertilizers, and RI+NPK. The recommended dose of chemical fertilizers was: $120 \mathrm{~kg} \mathrm{~N} \mathrm{ha}^{-1}$ as urea, $60 \mathrm{~kg}$ $\mathrm{P}_{2} \mathrm{O}_{5} \mathrm{ha}^{-1}$ as triple super phosphate, and $60 \mathrm{~kg} \mathrm{~K}_{2} \mathrm{O}$ ha $^{-1}$ as sulfate of potash. Plants were harvested at vegetative, flowering, and ripening stages. Data regarding number of tillers per plant, shoot length and dry weight, and root dry weight were recorded at all the three harvest stages. Similarly, data regarding panicle length, grain yield and 100 grains weight were recorded at ripening stage.

\section{Cultivation of subsequent wheat crop}

After the harvesting of rice crop, two wheat varieties ('Inqalab 91' and 'Punjab 96') were sown in same plots without any addition of NPK fertilizers or sunflower residue. Data regarding various plant growth and yield parameters were recorded at three growth stages similar to that of rice crop.

\section{Statistical analysis}

All the data were analyzed by ANOVA followed by Tukey's test to separate the treatment means using computer software SPSS 11.

\section{RESULTS}

\section{Effect of sunflower residue incorporation on growth} and yield of rice

The effect of incorporation of sunflower residue and NPK fertilizers on vegetative growth of rice is presented in Table 1. In rice 'Basmati Pak', sunflower RI insignificantly reduced the number of tillers and shoot length at all three growth stages. In contrast, RI significantly suppressed shoot biomass at vegetative stage. The effect of RI was insignificant on root biomass at all three growth stages. Rice 'Basmati Super' was comparatively tolerant to sunflower residue amendment. The effect was insignificant on all studied plant growth parameters in this variety. NPK fertilizers significantly enhanced shoot dry biomass at vegetative growth stage in 'Basmati Pak'. In general, various plant growth parameters were markedly suppressed when sunflower residue was incorporated in combination with NPK fertilizers as compared to NPK fertilizers alone. The effect was more pronounced in 'Basmati Pak' than in 'Basmati Super'.

The effect of sunflower RI and NPK fertilizers on various reproductive growth parameters of the two tested rice varieties is illustrated in Figure 1. In rice 'Basmati Pak', the highest panicle length was recorded in NPK fertilizers treatment. Incorporation of sunflower residue significantly reduced the panicle length as compared to

Table 1. Effect of sunflower residue incorporation (RI) on plant vegetative growth of two rice varieties at different growth stages.

\begin{tabular}{|c|c|c|c|c|c|c|c|c|c|c|c|c|}
\hline \multirow[b]{2}{*}{ Treatments } & \multicolumn{4}{|c|}{ Vegetative stage } & \multicolumn{4}{|c|}{ Flowering stage } & \multicolumn{4}{|c|}{ Ripening stage } \\
\hline & $\begin{array}{l}\text { Tillers } \\
\text { plant }^{-1}\end{array}$ & $\begin{array}{l}\text { Shoot } \\
\text { length }\end{array}$ & $\begin{array}{c}\begin{array}{c}\text { Shoot } \\
\text { dry } \\
\text { weight }\end{array} \\
\end{array}$ & $\begin{array}{c}\text { Root } \\
\text { dry } \\
\text { weight }\end{array}$ & $\begin{array}{l}\text { Tillers } \\
\text { plant }^{-1}\end{array}$ & $\begin{array}{l}\text { Shoot } \\
\text { length }\end{array}$ & $\begin{array}{c}\text { Shoot } \\
\text { dry } \\
\text { weight }\end{array}$ & $\begin{array}{c}\text { Root } \\
\text { dry } \\
\text { weight }\end{array}$ & $\begin{array}{l}\text { Tillers } \\
\text { plant }^{-1}\end{array}$ & $\begin{array}{l}\text { Shoot } \\
\text { length }\end{array}$ & $\begin{array}{c}\text { Shoot } \\
\text { dry } \\
\text { weight }\end{array}$ & $\begin{array}{c}\begin{array}{c}\text { Root } \\
\text { dry } \\
\text { weight }\end{array} \\
\end{array}$ \\
\hline & & $\mathrm{cm}$ & \multicolumn{2}{|c|}{$\longrightarrow \mathrm{g}$} & & $\mathrm{cm}$ & \multirow{2}{*}{\multicolumn{2}{|c|}{$\overline{\mathrm{g}}$}} & & \multirow[t]{2}{*}{$\mathrm{cm}$} & \multirow{2}{*}{\multicolumn{2}{|c|}{$\mathrm{g}$}} \\
\hline \multicolumn{8}{|c|}{ Rice var. Basmati Pak } & & & & & \\
\hline Control & $20 \mathrm{ab}$ & $79 b$ & $33.2 b$ & $6.6 b$ & $17 \mathrm{abc}$ & $92 \mathrm{ab}$ & $36.7 \mathrm{ab}$ & $6.9 \mathrm{abc}$ & $21 \mathrm{ab}$ & $88 \mathrm{a}$ & $35.0 \mathrm{ab}$ & $9.6 \mathrm{ab}$ \\
\hline RI & $15 \mathrm{bc}$ & $73 b c$ & $21.8 \mathrm{c}$ & $4.8 \mathrm{bc}$ & $15 \mathrm{abc}$ & $85 \mathrm{abc}$ & $25.0 \mathrm{bc}$ & $8.7 \mathrm{ab}$ & $15 b$ & $89 a$ & $25.3 \mathrm{bc}$ & $7.3 \mathrm{ab}$ \\
\hline NPK & $22 \mathrm{a}$ & $92 \mathrm{a}$ & $48.1 \mathrm{a}$ & $9.1 \mathrm{a}$ & $22 \mathrm{a}$ & $96 a$ & $47.1 \mathrm{a}$ & $11.9 \mathrm{a}$ & $27 \mathrm{a}$ & $91 \mathrm{a}$ & $46.8 \mathrm{a}$ & $18.2 \mathrm{a}$ \\
\hline $\mathrm{RI}+\mathrm{NPK}$ & $17 \mathrm{ab}$ & $84 \mathrm{ab}$ & $28.5 \mathrm{bc}$ & $6.6 \mathrm{~b}$ & $19 \mathrm{ab}$ & $90 \mathrm{ab}$ & $36.4 \mathrm{ab}$ & $10.4 \mathrm{ab}$ & $20 \mathrm{ab}$ & $88 \mathrm{a}$ & $33.5 \mathrm{ab}$ & $10.3 \mathrm{ab}$ \\
\hline \multicolumn{13}{|c|}{ Rice var. Basmati Super } \\
\hline Control & $10 \mathrm{~cd}$ & $52 \mathrm{~d}$ & $10.2 \mathrm{de}$ & $1.6 \mathrm{e}$ & $11 b c$ & $65 c$ & $17.3 \mathrm{c}$ & $5.3 \mathrm{bc}$ & $15 b$ & $70 b$ & $16.5 \mathrm{c}$ & $5.3 b$ \\
\hline RI & $7 d$ & $56 \mathrm{~d}$ & $7.4 \mathrm{e}$ & $1.4 \mathrm{e}$ & $11 b c$ & $72 b c$ & $13.7 \mathrm{c}$ & $4.5 b c$ & $14 \mathrm{~b}$ & $67 b$ & $14.9 \mathrm{c}$ & $3.5 \mathrm{~b}$ \\
\hline NPK & $14 \mathrm{bc}$ & $63 \mathrm{~cd}$ & $20.4 \mathrm{~cd}$ & $4.1 \mathrm{~cd}$ & $14 \mathrm{abc}$ & $73 b c$ & $20.5 b c$ & $5.4 \mathrm{bc}$ & $15 b$ & $68 b$ & $19.1 \mathrm{c}$ & $5.5 \mathrm{ab}$ \\
\hline $\mathrm{RI}+\mathrm{NPK}$ & $10 \mathrm{~cd}$ & $57 d$ & $10.6 \mathrm{~cd}$ & $1.9 \mathrm{de}$ & $10 \mathrm{c}$ & $65 \mathrm{c}$ & $11.1 \mathrm{c}$ & $1.9 \mathrm{c}$ & $14 b$ & $65 b$ & $14.5 \mathrm{c}$ & $3.2 \mathrm{~b}$ \\
\hline
\end{tabular}

In a column, values with different letters show significant difference as determined by Tukey's Test at $\mathrm{P} \leq 0.05$. 


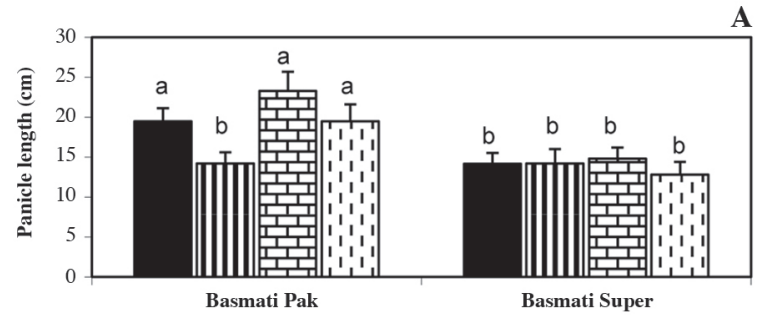

B
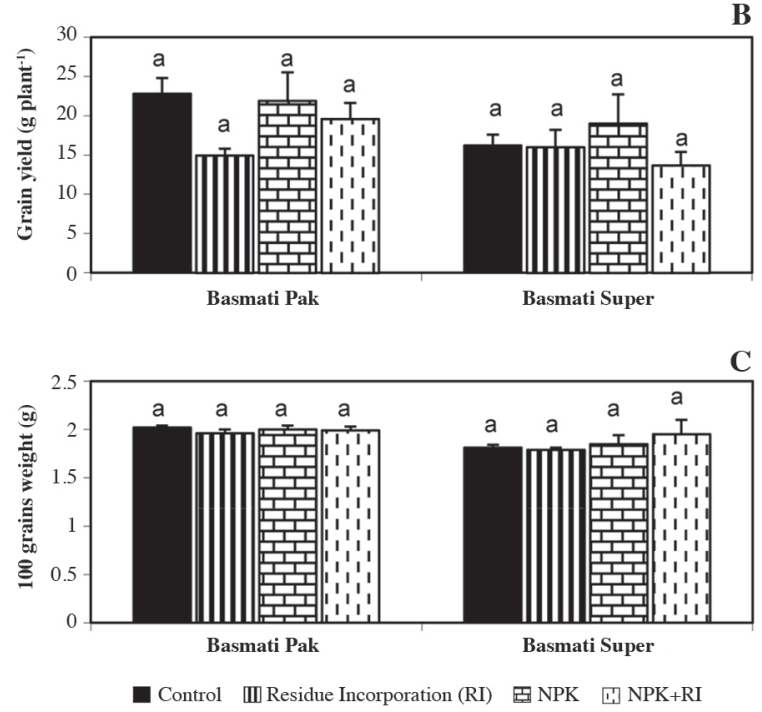

Vertical bars show standard errors of means of three replicates. Values with different letters show significant difference according to Tukey's test at $\mathrm{P} \leq 0.05$

Figure 1. Effect of sunflower residue incorporation (RI) on yield of two rice varieties.

control and other treatments. Addition of NPK fertilizers in combination with sunflower residues increased the panicle length significantly in this rice variety. In rice 'Basmati Super', the effect of various treatments on panicle length was insignificant as compared to control (Figure 1A). Grain yield in rice 'Basmati Pak' was reduced by $34 \%$ due to the application of sunflower residue. Application of NPK fertilizers markedly alleviated the allelopathic stress of sunflower residue. The effect of residue on grain yield of rice 'Basmati Super' was insignificant (Figure 1B). The effect of different treatments of sunflower residue and NPK fertilizers on 100 grain weight of the two rice varieties was insignificant (Figure 1C).

\section{Effect of sunflower residue incorporation on growth and yield of wheat}

Data regarding the effect of sunflower RI and NPK fertilizers on vegetative growth of wheat is summarized in Table 2. Incorporation of sunflower residue insignificantly reduced number of tillers at vegetative growth stages in 'Inqalab 91'. RI exhibited insignificant effect on shoot length in 'Inqalab 91' at all growth stages. However, residue application significantly reduced shoot length at flowering and ripening stages in 'Punjab 96'. Residue incorporation significantly declined shoot dry weight at vegetative stage in 'Inqalab 91'. In contrast, the effect of RI on this plant growth parameter of 'Punjab 96' was insignificant at all three growth stages. Although RI adversely affected root growth, this effect was statistically insignificant on root dry biomass in both wheat varieties. Application of NPK fertilizers generally enhanced root and shoot growth. The effect was more pronounced and significant at flowering and ripening stages than at vegetative growth stage. Wheat 'Punjab 96' showed more susceptibility to sunflower RI in the presence of NPK fertilizers as compared to 'Inqalab 91'. There was insignificant effect of RI and NPK on number of tillers at all three growth stages in 'Inqalab 91' as compared to NPK fertilizers alone. In contrast, in 'Punjab 96', a significant reduction in tillering was recorded at flowering and ripening stages. Shoot dry weight was significantly reduced at flowering stage only in 'Inqalab 91' while residue incorporation showed insignificantly effect on this plant growth parameter in 'Punjab 96'. Root dry weight was significantly reduced at flowering stage in 'Punjab 96', due to combined application of sunflower residue and NPK as compared to NPK fertilizers alone.

Table 2. Effect of sunflower residue incorporation (RI) on plant vegetative growth of two wheat varieties cultivated in the same field after harvesting the rice crop.

\begin{tabular}{|c|c|c|c|c|c|c|c|c|c|c|c|c|}
\hline \multirow[b]{2}{*}{ Treatments } & \multicolumn{4}{|c|}{ Vegetative stage } & \multicolumn{4}{|c|}{ Flowering stage } & \multicolumn{4}{|c|}{ Ripening stage } \\
\hline & $\begin{array}{l}\text { Tillers } \\
\text { plant }^{-1}\end{array}$ & $\begin{array}{l}\text { Shoot } \\
\text { length }\end{array}$ & $\begin{array}{c}\text { Shoot } \\
\text { dry } \\
\text { weight }\end{array}$ & $\begin{array}{c}\text { Root } \\
\text { dry } \\
\text { weight }\end{array}$ & $\begin{array}{l}\text { Tillers } \\
\text { plant }^{-1}\end{array}$ & $\begin{array}{l}\text { Shoot } \\
\text { length }\end{array}$ & $\begin{array}{c}\text { Shoot } \\
\text { dry } \\
\text { weight }\end{array}$ & $\begin{array}{c}\text { Root } \\
\text { dry } \\
\text { weight }\end{array}$ & $\begin{array}{l}\text { Tillers } \\
\text { plant }^{-1}\end{array}$ & $\begin{array}{l}\text { Shoot } \\
\text { length }\end{array}$ & $\begin{array}{c}\text { Shoot } \\
\text { dry } \\
\text { weight }\end{array}$ & $\begin{array}{c}\text { Root } \\
\text { dry } \\
\text { weight }\end{array}$ \\
\hline & & $\mathrm{cm}$ & \multicolumn{2}{|c|}{$\longrightarrow \mathrm{g}$} & & $\mathrm{cm}$ & \multicolumn{2}{|c|}{$-\mathrm{g}-$} & & $\mathrm{cm}$ & \multicolumn{2}{|c|}{$\longrightarrow \mathrm{g}$} \\
\hline & & & & & \multicolumn{3}{|c|}{ Wheat var. Inqalab 91} & & & & & \\
\hline Control & $7 \mathrm{ab}$ & $57 \mathrm{~b}$ & $6.5 \mathrm{ab}$ & $1.8 \mathrm{~b}$ & $7 \mathrm{bcd}$ & $72 \mathrm{a}$ & $13 \mathrm{~cd}$ & $3.1 \mathrm{c}$ & $12 \mathrm{bc}$ & $73 \mathrm{~b}$ & $27 \mathrm{~d}$ & $2.2 \mathrm{bc}$ \\
\hline RI & $4 \mathrm{c}$ & $56 \mathrm{~b}$ & $3.4 \mathrm{c}$ & $0.74 \mathrm{~b}$ & $6 \mathrm{~d}$ & $68 \mathrm{a}$ & $9 \mathrm{~d}$ & $2.8 \mathrm{c}$ & $10 \mathrm{c}$ & $71 \mathrm{bc}$ & $24 \mathrm{~d}$ & $2.1 \mathrm{bc}$ \\
\hline NPK & $8 \mathrm{a}$ & $57 \mathrm{~b}$ & $8.0 \mathrm{a}$ & $3.97 \mathrm{a}$ & $12 \mathrm{~b}$ & $69 a$ & $29 \mathrm{~b}$ & $7.1 \mathrm{bc}$ & $18 \mathrm{a}$ & $75 \mathrm{ab}$ & $46 a b$ & $4.3 \mathrm{a}$ \\
\hline $\mathrm{RI}+\mathrm{NPK}$ & $8 \mathrm{a}$ & $57 \mathrm{~b}$ & $7.7 \mathrm{a}$ & $2.3 \mathrm{ab}$ & $10 \mathrm{bcd}$ & $81 \mathrm{a}$ & $23 b c$ & $6.4 \mathrm{bc}$ & $13 b$ & $73 b$ & $28 \mathrm{~d}$ & $2.1 \mathrm{bc}$ \\
\hline \multicolumn{13}{|c|}{ Wheat var. Punjab 96} \\
\hline Control & $5 a b c$ & $54 \mathrm{~b}$ & $5.3 \mathrm{abc}$ & $1.60 \mathrm{~b}$ & $8 \mathrm{bcd}$ & $75 \mathrm{a}$ & $16 \mathrm{~cd}$ & $4.3 \mathrm{bc}$ & $10 \mathrm{c}$ & $73 b$ & $31 \mathrm{~cd}$ & $3.9 \mathrm{ab}$ \\
\hline RI & $5 a b c$ & $49 \mathrm{c}$ & $3.7 \mathrm{bc}$ & $0.72 b$ & $6 \mathrm{~d}$ & $74 a$ & $12 \mathrm{~cd}$ & $4.2 \mathrm{bc}$ & $10 \mathrm{c}$ & $67 \mathrm{c}$ & $26 \mathrm{~d}$ & $2.0 \mathrm{c}$ \\
\hline NPK & $7 \mathrm{ab}$ & $62 \mathrm{a}$ & $7.9 \mathrm{a}$ & $1.70 \mathrm{~b}$ & $18 \mathrm{a}$ & $84 a$ & $51 \mathrm{a}$ & $12.8 \mathrm{a}$ & $16 \mathrm{a}$ & $78 \mathrm{a}$ & $50 \mathrm{a}$ & $3.2 \mathrm{abc}$ \\
\hline RI+NPK & $6 a b c$ & $55 \mathrm{~b}$ & $5.6 \mathrm{abc}$ & $1.15 b$ & $11 b c$ & $77 \mathrm{a}$ & $27 \mathrm{~b}$ & $8.1 \mathrm{~b}$ & $12 \mathrm{bc}$ & $75 \mathrm{ab}$ & $38 \mathrm{bc}$ & 3.1abc \\
\hline
\end{tabular}

In a column, values with different letters show significant difference as determined by Tukey's Test at $\mathrm{P} \leq 0.05$. 
Data about the effect of sunflower RI and NPK fertilizers on various reproductive growth parameters of the two tested wheat varieties is shown in Figure 2. In both wheat varieties, the effect of sunflower RI was insignificant on ear length and grain yield and 100 grains weight (Figures 2A-C). NPK fertilizers alone significantly enhanced ear length in both wheat varieties as compared to control. Ear length was significantly reduced in both wheat varieties in combined application RI+NPK as compared to NPK fertilizers alone (Figure 2A). Grain yield was significantly enhanced by $39 \%$ and $31 \%$ in 'Inqalab 91' and 'Punjab 96', respectively, due to NPK fertilizers as compared to control. However, there was significant decrease of $41 \%$ in grain yield in 'Inqalab 91' when RI+NPK was applied as compared to NPK fertilizers alone. By contrast, in 'Punjab 96', there was insignificant difference in grain yield between NPK fertilizers alone and RI+NPK treatments (Figure 2B).

\section{DISCUSSION}

In the present study, two varieties of rice were cultivated in field soil amended with sunflower residue with or without application of recommended dose of NPK fertilizers. In rice 'Basmati Pak', sunflower RI significantly reduced shoot
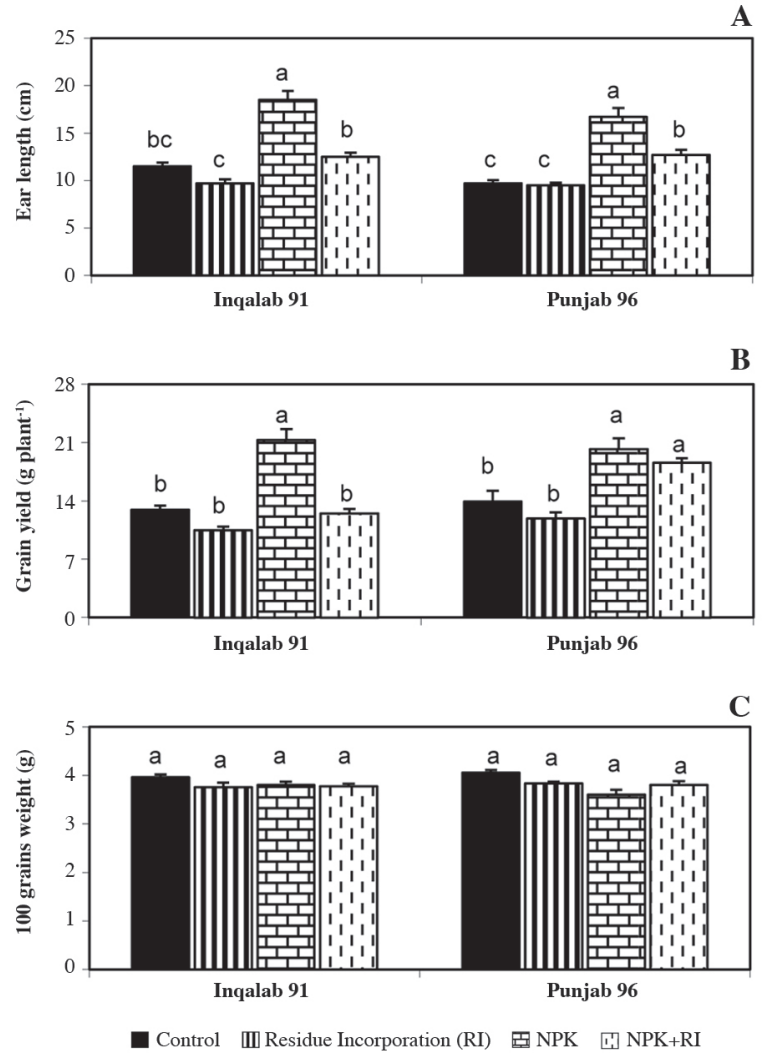

Vertical bars show standard errors of means of three replicates. Values with different letters show significant difference according to Tukey's test at $\mathrm{P} \leq 0.05$.

Figure 2. Effect of sunflower residue incorporation (RI) on yield of two wheat varieties cultivated in the same field after harvesting rice crop. biomass and grain yield. Earlier, Morris and Parrish (1992) observed declined yield of winter wheat when sunflower residues were tilled into the soil. Similarly, Batish et al. (2002) reported decreased germination, growth, and yield of four summer season crops namely millet, sorghum, corn, and clusterbean, when grown in fields containing sunflower residues. Recently, Ashrafi et al. (2008) found that soil incorporation of fresh sunflower roots and both roots and shoots reduced wild barley (Hordeum spontaneum $\mathrm{K}$. Koch.) germination, plant height and weight when compared with a no-residue control. The reduced plant growth in soil amended with sunflower RI could be attributed to the presence of allelochemicals in different parts of sunflower. Many terpenes and phenols have been reported in different sunflower cultivars (Ghafar et al., 2001; Macias et al., 2004). These allelochemicals are often water-soluble substances which are released into the surrounding environment through root exudation, leaching and decomposition of plant residues (Ashrafi et al., 2008), and adversely affect germination and growth of other plants (Batish et al., 2002).

After harvesting rice crop, two varieties of wheat ('Inqalab 91' and 'Punjab 96') were cultivated in same plots without any further addition of sunflower residue or NPK fertilizers. The negative effect of the RI on root and shoot growth as well as grain yield of the two wheat varieties was not as much pronounced as was in case of the two rice varieties. It could be due to degradation of allelochemicals in the soil by physical, chemical, and microbial processes (Katase, 1981; Hess et al., 1992; Vidal and Bauman, 1992). However, in treatments where $\mathrm{RI}+\mathrm{NPK}$ was applied in previous rice crop, the response of the two wheat varieties was different. In case of 'Inqalab 91', a significant reduction in grain yield was recorded in RI+NPK application as compared to NPK fertilizers alone. In contrast, in 'Punjab 96', the effect was insignificant on grain yield. Since, generally NPK fertilizers are applied in rice crop, thus wheat 'Punjab 96' is more suitable for cultivation under sunflower allelopathic stress than 'Inqalab 91'.

The results of the present study clearly demonstrate the genotypic variation in growth and yield response of different varieties of rice and wheat to allelopathic stress caused by decomposing sunflower residue. Between the two rice varieties, 'Basmati Super' was comparatively more tolerant to allelopathic stress of sunflower residue than 'Basmati Pak'. Similarly, the adverse effect of RI on grain yield was more pronounced on wheat 'Inqalab 91' than on yield in 'Punjab 96'. Earlier, Javaid et al. (2007) reported genotypic variation in rice cultivars against allelopathic stress of Cyperus rotundus L. They reported that rice 'IRRI-8' and 'IRRI-Fine' were more tolerant to phytotoxicity of $C$. rotundus than various Basmati varieties viz. 'Pak Basmati', 'Basmati Super', and 'Basmati 385'. Genotypic variation in tolerance to allelopathy has also been reported in other crop-allelopathic plants interactions (Table 3). This unequal susceptibility of various rice 
Table 3: Genotypic variation in tolerance to allelopathic stress.

\begin{tabular}{|c|c|c|c|c|}
\hline Allelopathic plants & Allelochemicals/extracts & Target Crop & Effect & References \\
\hline \multirow[t]{2}{*}{$\begin{array}{l}\text { Sunflower (Helianthus } \\
\text { annuus L.) }\end{array}$} & $\begin{array}{l}\text { Aqueous extracts of root, } \\
\text { stem and leaves. }\end{array}$ & 4 wheat varieties. & $\begin{array}{l}\text { The aqueous extract of three sunflower varieties } \\
\text { tested against wheat varieties significantly } \\
\text { decreased biomass of wheat seedlings, especially at } \\
\text { concentrations of } 40 \% \text { and } 50 \% \text {. }\end{array}$ & Anjum and Bajwa (2010) \\
\hline & & 4 rice varieties. & $\begin{array}{l}\text { Showed variable effect on growth and yield of rice } \\
\text { varieties. }\end{array}$ & Bashir et al. (2011) \\
\hline $\begin{array}{l}\text { Eucalyptus } \\
\text { camaldulensis Dehnh. }\end{array}$ & $\begin{array}{l}\text { Aqueous extracts of } \\
\text { different parts of the plant. }\end{array}$ & 12 wheat varieties. & $\begin{array}{l}\text { Aqueous extracts showed variable adverse affect } \\
\text { on the germination, growth and yield of different } \\
\text { wheat varieties. }\end{array}$ & Khan et al. (2008) \\
\hline $\begin{array}{l}\text { Albizia saman (Jacq.) } \\
\text { Merr. }\end{array}$ & $\begin{array}{l}\text { Aqueous extract of } \\
\text { different parts. }\end{array}$ & $\begin{array}{l}3 \text { varieties of Zea } \\
\text { mays, and } 4 \text { varieties. } \\
\text { of Triticum aestivum. }\end{array}$ & $\begin{array}{l}\text { Leaf, stem, root and seeds extracts delayed } \\
\text { germination and variably inhibited seedling growth } \\
\text { of the test spp. }\end{array}$ & Mehar and Khan (1994) \\
\hline $\begin{array}{l}\text { Polypogon } \\
\text { monspeliensis (L.) Desf. }\end{array}$ & $\begin{array}{l}\text { Aqueous extracts from } \\
\text { various parts, including } \\
\text { shoots, inflorescences. }\end{array}$ & 2 wheat varieties. & $\begin{array}{l}\text { Aqueous extracts from various parts, including } \\
\text { shoots, inflorescences, variably affected the } \\
\text { germination, plumule and radical growth, number } \\
\text { of seminal roots, and biomass of two wheat } \\
\text { varieties }\end{array}$ & Sarah et al. (2011) \\
\hline Cyperus rotundus $\mathrm{L}$. & $\begin{array}{l}\text { Aqueous leaf and tuber } \\
\text { extract. }\end{array}$ & 6 rice varieties. & $\begin{array}{l}\text { Three Basmati varieties and KS- } 282 \text { were exhibited } \\
\text { significantly losses in root and shoot growth while } \\
\text { other two are tolerant }\end{array}$ & Javaid et al. (2007) \\
\hline
\end{tabular}

varieties to the sunflower extracts could be due to inherent differences in physiological and morphological characteristics of various genotypes involved (Macias et al., 1992).

\section{CONCLUSIONS}

The present study concludes that the adverse effects of sunflower residue incorporation on rice and subsequent wheat crop can be reduced by cultivation of allelopathic tolerant varieties. Rice 'Basmati Super' is more suitable than 'Basmati Pak' for cultivation under allelopathic stress of sunflower followed by cultivation of wheat 'Punjab 96' as grain yield in these varieties is not significantly affected due to sunflower residue incorporation in combination with NPK fertilizers.

Efectos alelopáticos de residuos de girasol sobre el crecimiento de arroz y cultivo de trigo subsecuente. El girasol (Helianthus annuus L.) es una planta alelopática bien conocida. Sin embargo, los agricultores de Paquistán generalmente incorporan el residuo de girasol en el suelo con el objetivo de mejorar la fertilidad y la materia orgánica del suelo. Los experimentos de campo se realizaron para evaluar el efecto de la incorporación de residuos de girasol en el crecimiento y producción de arroz (Oryza sativa L.) y trigo (Triticum aestivum L.) subsecuente. Para el cultivo de arroz hubo cuatro tratamientos viz. Control, incorporación de residuo de girasol (RI), fertilizantes NPK, y NPK+RI. Se cultivaron dos variedades de arroz (Basmati Pak y Basmati Super). La incorporación de residuo de girasol redujo marcadamente crecimiento de planta y producción en 'Basmati Pak'. Hubo una reducción de $34 \%$ en producción de esta variedad debida a RI. 'Basmati Super' fue tolerante a alelopatía del girasol, siendo el efecto de RI generalmente insignificante en crecimiento de planta y producción de grano. Dos variedades comúnmente cultivadas de trigo (Inqalab 91 y Punjab 96) se sembraron en las mismas parcelas después de cosechar el arroz, sin adición de RI o NPK. En 'Punjab 96', el efecto de RI o RI+NPK fue insignificante en rendimiento de grano. En contraste, en 'Inqalab 91', RI+NPK redujo significativamente la producción de grano, $41 \%$ comparado con NPK solo. El presente estudio concluyó que el arroz 'Basmati Super' y trigo 'Punjab 96' son apropiados para cultivo bajo estrés alelopático de girasol.

Palabras clave: Alelopatía, tolerancia genotípica, Oryza sativa, Helianthus annuus, Triticum aestivum.

\section{LITERATURE CITED}

Al-Tawaha, A.R.M., and N. Odat. 2010. Use of sorghum and maize allelopathic properties to inhibit germination and growth of wild barley (Hordeum spontaneum). Notulae Botanicae Horti Agrobotanici Cluj-Napoca 38:124-127.

Anjum, T., and R. Bajwa. 2010. Sunflower phytochemicals adversely affect wheat yield. Natural Product Research 24:825-837.

Ashrafi, Z.Y., S. Sadeghi, H.R. Mashhadi, and M.A. Hassan. 2008. Allelopathic effects of sunflower (Helianthus annuus) on germination and growth of wild barley (Hordeum spontaneum). Journal of Agricultural Technology 4:219-229.

Bashir, U., A. Javaid, and R. Bajwa. 2011. Comparative tolerance of different rice varieties to sunflower phytotoxicity. Journal of Medicinal Plants Research 5:6243-6248.

Batish, D., P. Tung, H. Singh, and R. Kohli. 2002. Phytotoxicity of sunflower residues against some summer season crops. Journal of Agronomy and Crop Sciences 188:19-24.

Bogatek, R., A. Gniazdowska, W. Zakrzewska, K. Oracz, and S.W. Gawroński. 2006. Allelopathic effects of sunflower extracts on mustard seed germination and seedling growth. Biologia Plantarum 50:156-158.

Chattopadhyay, S.P. 1995. Allelopathic potential of Solanum myriacanthum Dunal (Solanaceae) in relation to seed germination and seedling growth of mustard (Brassica). Acta Botanica Indica 23:29-31

Cheema, Z.A., A. Khaliq, and S. Saeed. 2004. Weed control in maize (Zea mays L.) through sorghum allelopathy. Journal of Sustainable Agriculture 23:73-86. 
Ghafar A., B. Saleem, Anwar-ul-Haq, and M.J. Qureshi. 2001. Isolation and identification of allelochemicals of sunflower (Helianthus annuus L.) International Journal of Agriculture \& Biology 3:20-22.

Hess, D.E., G. Ejeta, and L.G. Buttler. 1992. Selecting sorghum genotypes expressing a quantitative biosynthetic trait that confers resistance to Striga. Phytochemistry 31:493-497.

Hisashi, K.N. 2004. Allelopathic substance in rice root exudates: Rediscovery of momilactone B as an allelochemical. Journal of Plant Physiology 161:271-276.

Ioannis, V., D. Kico, and E. Ilias. 2005. Allelopathic potential of Bermudagrass and Johnsongrass and their interference with cotton and corn. Agronomy Journal 97:303-313.

Javaid, A., R. Bajwa, N. Rabbani, and T. Anjum. 2007. Comparative tolerance of rice (Oryza sativa L.) genotypes to purple nutsedge (Cyperus rotundus L.) allelopathy. Allelopathy Journal 20:157166.

Javaid, A., S. Shafique, S. Shafique, and T. Riaz. 2008. Effect of rice extracts and residue incorporation on Parthenium hysterophorus management. Allelopathy Journal 22:353-362.

Kamal, J., and A. Bano. 2008. Allelopathic potential of sunflower (Helianthus annuus L.) on soil metals and its leaves extracts on physiology of wheat (Triticum aestivum L.) seedlings. African Journal of Biotechnology 7:3261-3265.

Kamal, J., and A. Bano. 2009. Efficiency of allelopathy of sunflower (Helianthus annuus L.) on physiology of wheat (Triticum aestivum L.) African Journal of Biotechnology 8:3555-3559.

Katase, T. 1981. Stereoisomerization of p-coumaric and ferulic acids during their incubation in peat soil extract solution by exposure to fluorescent light. Soil Science and Plant Nutrition 27:421-427.

Kausar, S. 1999. Identification of allelochemicals in root/shoot of sunflower and their effect on mungbean germination. M.Sc. Thesis. University of Agriculture, Faisalabad, Pakistan.

Kawata, Y., I. Harada, and T. Matsunaka. 1996. Allelopathic interaction of alfalfa (Medicago sativa L.) root exudates. Journal of Rakuno Gakuen University. Natural Science 21:79-86.

Khan, M.A., I. Hussain, and E.A. Khan. 2008. Allelopathic effects of Eucalyptus (Eucalyptus camaldulensis L.) on germination and seedling growth of wheat (Triticum aestivum L.) Pakistan Journal of Weed Science Research 14:9-18.
Khanh, T.D., I.M. Chung, T.D. Xuan, and S. Tawata. 2005. The exploitation of crop allelopathy in sustainable agricultural production. Journal of Agronomy and Crop Science 191:172-184.

Macias, F.A., J.C.G. Galindo, and G.M. Massanet. 1992. Potential allelopathic activity of several sesquiterpene lactone models. Phytochemistry 31:1969-1977.

Macias, F.A., A. Lopez, R.M. Varela, A. Torres, and J.M.G. Molinillo. 2004. Bioactive apocarotenoids annuionones F and G: structural revision of annuionones A, B and E. Phytochemistry 65:3057-3063.

Mehar, N., and M.A. Khan. 1994. Allelopathic potential of Albizia saman Merr. Pakistan Journal of Botany 26:139-147.

Morris, P., and D. Parrish. 1992. Effects of sunflower residues and tillage on winter wheat. Field Crops Research 29:317-327.

Mushtaq, M.N., Z.A. Cheema, and S.A. Bazmi. 2003. Allelopathic effects of sunflower aqueous extracts on germination of wheat and some important wheat weeds. Pakistan Journal of Scientific Research 55:71-75.

Nielsen, K.F., T. Cuddy, and W. Woods. 1960. The influence of the extract of some crops and soil residues on germination and growth. Canadian Journal of Plant Science 40:188-197.

Oleszek, W., and M. Jurzysta. 1987. An allelopathic potential of alfalfa root medicagenic acid glycosides and their fate in soil environments. Plant and Soil 98:67-80.

Roth, C.M., J.P. Shroyer, and G.M. Paulsen. 2000. Allelopathy of sorghum on wheat under several tillage systems. Agronomy Journal 92:855-860.

Sarah, S., F. Hussain, M. Ehsan, and T. Burni. 2011. Allelopathic potential of Polypogon monspeliensis L. against two cultivars of wheat. African Journal of Biotechnology 10:19723-19728.

Sedigheh, S.R., A. Rahnavard, and Z.Y. Ashrafi. 2010. Allelopathic effect of Helianthus annuus (sunflower) on Solanum nigrum (black nightshade) seed germination and growth in laboratory condition. Journal of Horticultural Science and Ornamental Plants 2:32-37.

Vidal, R.A., and T.T. Bauman. 1992. Fate of allelochemicals in the soil. Ciencia Rural 27:351-357.

Wardle, D.A., M. Ahmad, and K.S. Nicholson. 1991. Allelopathic influence of nodding thistle (Cardus nutans L.) seed on germination and radicle growth of pasture plants. New Zealand Journal of Agriculture Research 34:185-191. 